\title{
A study on electrospray mass spectrometry of fullerenol $\mathrm{C}_{60}(\mathrm{OH})_{24}$
}

\author{
Mihaela Silion ${ }^{1}$, Andrei Dascalu $^{* 1}$, Mariana Pinteala*1, \\ Bogdan C. Simionescu ${ }^{1,2}$ and Cezar Ungurenasu ${ }^{1}$
}

\section{Full Research Paper}

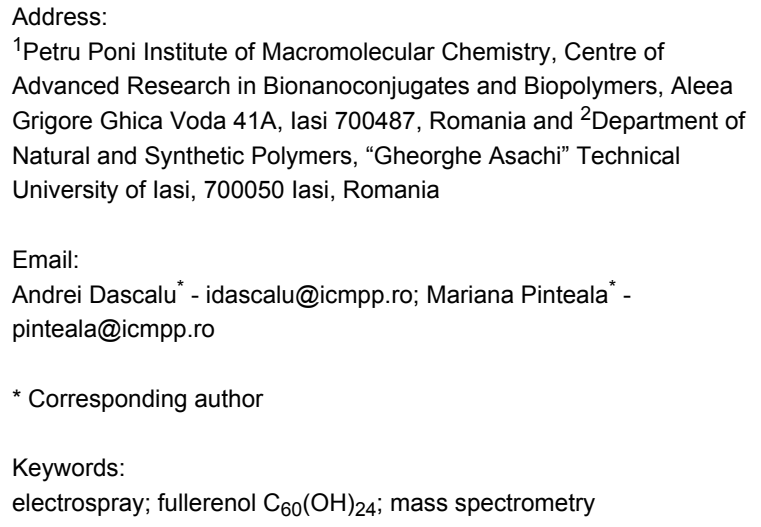

${ }^{1}$ Petru Poni Institute of Macromolecular Chemistry, Centre of Advanced Research in Bionanoconjugates and Biopolymers, Aleea Grigore Ghica Voda 41A, lasi 700487, Romania and 2Department of Natural and Synthetic Polymers, "Gheorghe Asachi" Technical University of lasi, 700050 lasi, Romania

Email:

Andrei Dascalu* - idascalu@icmpp.ro; Mariana Pinteala* pinteala@icmpp.ro

${ }^{*}$ Corresponding author

Keywords:

electrospray; fullerenol $\mathrm{C}_{60}(\mathrm{OH})_{24}$; mass spectrometry

Beilstein J. Org. Chem. 2013, 9, 1285-1295. doi:10.3762/bjoc. 9.145

Received: 05 March 2013

Accepted: 31 May 2013

Published: 02 July 2013

Associate Editor: H. Ritter

(C) 2013 Silion et al; licensee Beilstein-Institut. License and terms: see end of document.

\begin{abstract}
Full characterization of fullerenol $\mathrm{C}_{60}(\mathrm{OH})_{24}$ by HPLC ESI-MS in negative and positive ionization modes was achieved. Fragmentor voltage and capillary voltage were optimized in order to obtain a good signal stability and the best peak intensity distribution for the fullerenol $\mathrm{C}_{60}(\mathrm{OH})_{24}$ in both negative and positive modes. While the predominant base peak observed for $\mathrm{C}_{60}(\mathrm{OH})_{24}$ in the negative ionization mode was $[\mathrm{M}-\mathrm{H}]^{-}$at $m / z 1127$, those observed in the positive mode were multiply charged $\left[\mathrm{M}-\mathrm{H}_{2} \mathrm{O}+\right.$ $4 \mathrm{H}]^{4+}$ at $m / z 279$ and $\left[\mathrm{M}-12 \mathrm{H}_{2} \mathrm{O}+2 \mathrm{NH}_{3}+6 \mathrm{H}\right]^{6+}$ at $m / z 158$.
\end{abstract}

\section{Introduction}

Because of their potential for chemical tunability and exciting range of biological activities as glutamate-receptor antagonists [1] and antiproliferative [2,3], neuroprotective [4-7], and anticancer agents [8-13], polyhydroxylated [ $\left.\mathrm{C}_{60}\right]$ fullerenes, $\mathrm{C}_{60}(\mathrm{OH})_{\mathrm{x}}$, have received much attention in recent years. However, to the best of our knowledge, except for the compositionally and structurally well characterized $\mathrm{C}_{60}(\mathrm{OH})_{24}$, prepared by alkaline hydrolysis of $\mathrm{C}_{60} \mathrm{Br}_{24}[14,15]$, most of these fullerenols are not pure $\mathrm{C}_{60}(\mathrm{OH})_{\mathrm{x}}$, but a complex mixture of products with an average composition of $\mathrm{C}_{60}(\mathrm{OH})_{\mathrm{x}-\mathrm{y}}$, $\mathrm{C}_{60} \mathrm{O}_{\mathrm{x}}(\mathrm{OH})_{\mathrm{y}}[16-19]$ or $\mathrm{C}_{60}(\mathrm{OH})_{\mathrm{x}}(\mathrm{ONa})_{\mathrm{y}}[20]$.

Therefore, the HPLC separation and accurate measurement of the molecular weight for structure characterization by electrospray ionization mass spectrometry (ESI-MS) have become essential for fullerenol research. Fullerenols $\mathrm{C}_{60}(\mathrm{OH})_{18-44}$ are very small neutral molecules with the highest density of hydroxy groups on a given particle surface (up to $10.7 \mathrm{OH} / \mathrm{nm}^{2}$ ) 
[21] achieved so far, complicating spectra acquisition if the correct conditions are not used. Initial attempts made by Isaacson et al [22] in 1994 to develop mass-spectrometric methods for fullerenols using ESI-MS with commercially available $\mathrm{C}_{60}(\mathrm{OH})_{24}$ and $\mathrm{C}_{60}(\mathrm{OH})_{22-24}$ dissolved in acidic, basic, and neutral solutions did not produced ions diagnostic of $\mathrm{C}_{60}(\mathrm{OH})_{\mathrm{x}}$. Afterwards, very few isolated attempts have been made on the identification of fullerenols [23] and/or their derivatives [24-28] by ESI-MS analysis, and very little detail was provided. We carried out an experimental investigation on ESI-MS of fullerenol $\mathrm{C}_{60}(\mathrm{OH})_{24}$ over a wide range of total capillary and fragmentor voltages.

Herein, we are happy to report the first experimental evidences that fullerenols are ESI-MS-inactive compounds in aqueous media at low and medium capillary and fragmentor voltage under negative ionization conditions, but they are ESI-MSactive compounds in aqueous and ammonia media, in both negative and positive ionization mode at a capillary voltage of $4.5 \mathrm{kV}$ and a fragmentor voltage of $400 \mathrm{~V}$ with no $\mathrm{C}_{60}$-cage fragmentation.

\section{Results and Discussion}

\section{Nomenclature and ionization mechanisms}

In the discussion, we will use the expressions protonated $[\mathrm{M}+$ $\mathrm{H}]^{+}$and deprotonated $[\mathrm{M}-\mathrm{H}]^{-}$molecules, and distonic deprotonated molecules for those identified from a deprotonated molecule plus loss of $\mathrm{HO}^{\bullet}$ and/or $\mathrm{H}^{\bullet}$ radicals $\left[\mathrm{M}-\mathrm{HO}^{\bullet}-\mathrm{H}^{\bullet}-\right.$
$\mathrm{H}]^{-}$. However, while only radical-ion pairs have been identified by ESI-MS as distonic ions, the distonic deprotonated molecules observed in (-)ESI-MS spectra of $\mathrm{C}_{60}(\mathrm{OH})_{24}$ contain a different number of charges and radicals on the $\mathrm{C}_{60}$ cage. Consequently, these distonic species should be described as quasi-distonic radical anions. The proposed mechanisms for the formation of fullerenol $\mathrm{C}_{60}(\mathrm{OH})_{24}$ anions and distonic radical anions are shown in Scheme 1.

For naming these individual radical species using "yl" and "oxyl" suffixes the terms fullerenyl for radicals generated by the loss of $\mathrm{HO}^{\circ}(\mathrm{M} 1$ in Scheme 1) and fullerenoxyl for radicals generated by the loss of $\mathrm{H}^{\bullet}$ (M2 in Scheme 1) will be used (IUPAC 2002) [29]. Radical anions formed by electron addition to a fullerenyl radical shall be described as fullerene carbanions and referred to as fullerenide anions (M3 in Scheme 1) and $[\mathrm{mM}+\mathrm{ne}]^{\mathrm{m}-\mathrm{n} \cdot}$ shall be described as molecular anions. As regards to the observation of distonic fullerenylfullerenate M7 ions, such distonic dehydroalcoxide radical anions, namely dehydrophenoxide radical anions, were first observed by Bowie et al [30] and recently investigated by ESIMS by Mariappandar et al [31].

Anions formed by the deprotonation of $\mathrm{OH}$ (M4 in Scheme 1) shall be named as fullerenate anions. Consequently, the ions M6 shall be named fullerenide-fullerenate anions, and ions M5 and M7 shall be named fullerenoxyl-fullerenate and fullerenylfullerenate distonic anions, respectively. To avoid any confu-

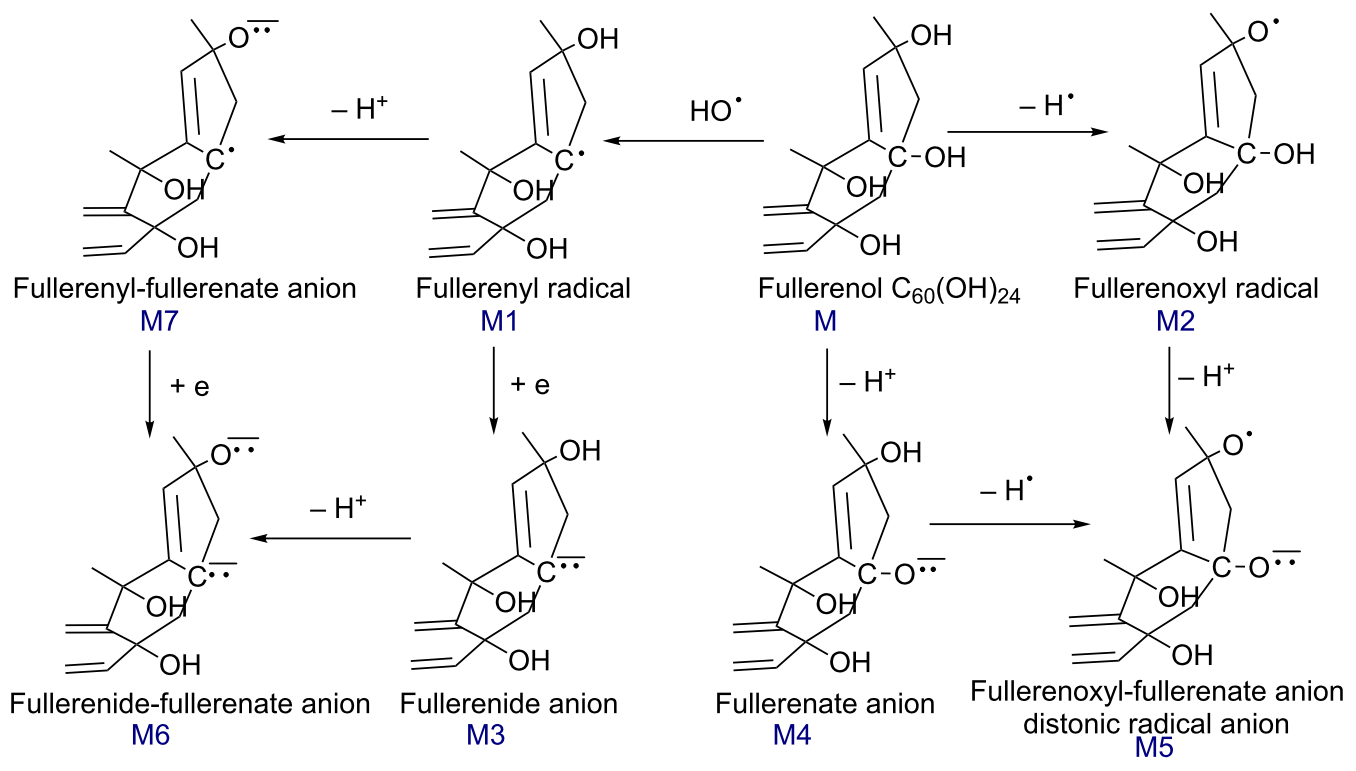

Scheme 1: Proposed mechanisms for the formation of fullerenol anions and distonic radical anions observed by $(-) \mathrm{ESI}_{-\mathrm{MS}}$ spectra of $\mathrm{C}_{60}(\mathrm{OH})_{24}$ in pure water. 
sion with dissociative electron attachment (DEA) (addition of a free electron to a gas-phase molecule to give an anion and a neutral molecule via a superexcited anion), the term quasi-electron-capture will be used for the addition of an electron to a fullerenyl radical M7 to generate a carbanion M6.

\section{Negative-ionization-mode mass spectra}

The negative-ion ESI-MS spectra and ionization data of $\mathrm{C}_{60}(\mathrm{OH})_{24}$ in ultrapure water and in the presence of small amounts of aqueous ammonia will be discussed here.

\section{Fullerenol in pure water}

Three distinct regions can be identified in the mass spectra: $\mathrm{m} / \mathrm{z}$ 100-600, $\mathrm{m} / \mathrm{z}$ 600-1500 (Figure $1 \mathrm{~b}$ ) and above $\mathrm{m} / \mathrm{z} 1500$. Between $\mathrm{m} / \mathrm{z} 600$ and 1500 , the most abundant ion is centered at $\mathrm{m} / \mathrm{z} 1127$ and corresponds to the singly charged base molecular ion $[\mathrm{M}-\mathrm{H}]^{-}$generated through the deprotonation of fullerenol $\mathrm{C}_{60}(\mathrm{OH})_{24}$.

As shown in Table 1 (entries 1-3) and Scheme 2, consecutive weight loss of 18 mass units from the deprotonated molecule

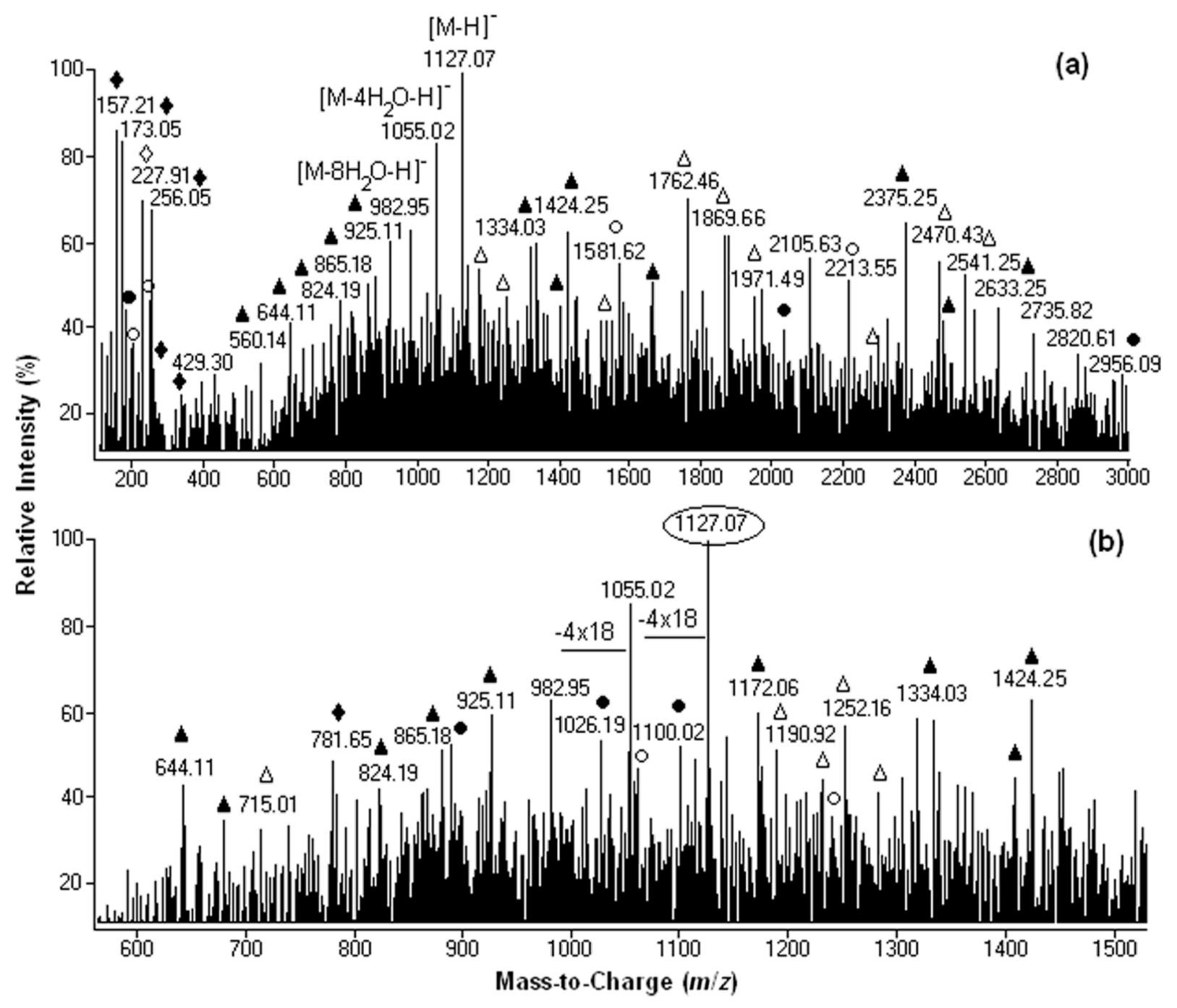

Figure 1: Negative-ion mass spectra for a $0.5 \times 10^{-5} \mathrm{M}$ solution of $\mathrm{C}_{60}(\mathrm{OH})_{24}$ in ultrapure water: (a) full scan spectrum (b) $\mathrm{m} / \mathrm{z}$ range $600-1500$. $\left(\bullet\left[\mathrm{M}(\mathrm{n})-n \mathrm{H}_{2} \mathrm{O}-\mathrm{xH}\right]^{\mathrm{x}-}, \mathbf{\Delta}\left[\mathrm{M}(\mathrm{n})+n \mathrm{H}_{2} \mathrm{O}(\mathrm{m})-\mathrm{xH}\right]^{\mathrm{x}-}, \bullet\left[\mathrm{M}(\mathrm{n})-\mathrm{H}_{2} \mathrm{O}(\mathrm{m})-\mathrm{yHO}+\mathrm{ye}-\mathrm{xH}\right]^{(\mathrm{x}+\mathrm{y})-}, \circ\left[\mathrm{M}(\mathrm{n})-m \mathrm{H}_{2} \mathrm{O}-\mathrm{yH} \mathrm{H}^{\bullet}-\mathrm{xH}\right]^{\mathrm{x}-\mathrm{y} \bullet-}, \Delta\left[\mathrm{M}(\mathrm{n})+\mathrm{H}_{2} \mathrm{O}(\mathrm{m})-\right.\right.$ $\left.\left.\mathrm{yH}^{\bullet}-\mathrm{xH}\right]^{\mathrm{x}-\mathrm{y} \cdot-}, \diamond\left[\mathrm{M}-m \mathrm{H}_{2} \mathrm{O}-\mathrm{yHO}-\mathrm{zH}^{\bullet}-\mathrm{xH}\right]^{\mathrm{x}-(\mathrm{y}+\mathrm{z}) \cdot-}\right)$. 
Table 1: Summary of the dominant ESI-MS negative ionic species of fullerenol $\mathrm{C}_{60}(\mathrm{OH})_{24}$ in ultrapure water (relative abundance, assignments, and $\mathrm{m} / \mathrm{z}$ values) at $4.5 \mathrm{kV}$ capillary voltage and $400 \mathrm{~V}$ fragmentor voltage.

\begin{tabular}{|c|c|c|c|c|c|}
\hline \multirow{2}{*}{ Entry } & \multirow{2}{*}{ Relative intensity (\%) ${ }^{a}$} & \multirow{2}{*}{ Assignments } & \multicolumn{3}{|c|}{$m / z$} \\
\hline & & & Calculated & Found & Deviation \\
\hline 1 & 100 & {$[\mathrm{M}-1 \mathrm{H}]^{-}$} & 1127.0570 & 1127.0719 & -0.0149 \\
\hline 2 & 83 & {$\left[\mathrm{M}-4 \mathrm{H}_{2} \mathrm{O}-1 \mathrm{H}\right]^{-}$} & 1055.0146 & 1055.0172 & -0.0026 \\
\hline 3 & 63 & {$\left[\mathrm{M}-8 \mathrm{H}_{2} \mathrm{O}-1 \mathrm{H}\right]^{-}$} & 982.9722 & 982.9495 & 0.0227 \\
\hline 4 & 55 & {$\left[\mathrm{M}+7 \mathrm{H}_{2} \mathrm{O}-1 \mathrm{H}^{\bullet}-1 \mathrm{H}^{-1} \cdot\right.$} & 1252.1234 & 1252.1617 & -0.0383 \\
\hline 5 & 54 & {$\left[2 \mathrm{M}+12 \mathrm{H}_{2} \mathrm{O}-1 \mathrm{H}^{\bullet}-1 \mathrm{H}\right]^{-1 \bullet}$} & 2470.2432 & 2470.4280 & -0.1848 \\
\hline 6 & 54 & {$\left[3 \mathrm{M}-12 \mathrm{H}_{2} \mathrm{O}-3 \mathrm{H}^{\bullet}-2 \mathrm{H}^{2-3 \cdot}\right.$} & 1581.5141 & 1581.6201 & -0.1060 \\
\hline 7 & 63 & {$\left[3 \mathrm{M}+20 \mathrm{H}_{2} \mathrm{O}-3 \mathrm{H}^{\bullet}-2 \mathrm{H}\right]^{2-3 \cdot}$} & 1869.6852 & 1869.6562 & 0.0290 \\
\hline 8 & 20 & {$\left[\mathrm{M}-8 \mathrm{H}_{2} \mathrm{O}-3 \mathrm{OH}^{\bullet-} 3 \mathrm{H}\right]^{3-3 \bullet}$} & 309.9961 & 309.9241 & 0.0720 \\
\hline 9 & 51 & {$\left[2 \mathrm{M}+19 \mathrm{H}_{2} \mathrm{O}-3 \mathrm{H}\right]^{3-}$} & 865.1027 & 865.1792 & -0.0765 \\
\hline 10 & 52 & {$\left[3 \mathrm{M}+18 \mathrm{H}_{2} \mathrm{O}-12 \mathrm{H}^{\bullet}-3 \mathrm{H}\right]^{3-12 \cdot}$} & 1231.0894 & 1231.0091 & 0.0803 \\
\hline 11 & 49 & {$\left[4 \mathrm{M}+9 \mathrm{H}_{2} \mathrm{O}-9 \mathrm{H}^{\bullet}-3 \mathrm{H}\right]^{3-9 \cdot}$} & 1554.0869 & 1554.0754 & 0.0115 \\
\hline 12 & 65 & {$\left[6 \mathrm{M}+2 \mathrm{OH}_{2} \mathrm{O}-3 \mathrm{H}\right]^{3-}$} & 2375.1924 & 2375.2462 & -0.0538 \\
\hline 13 & 71 & {$\left[\mathrm{M}-4 \mathrm{H}_{2} \mathrm{O}-4 \mathrm{H}^{\bullet}-8 \mathrm{HO}^{\bullet}-4 \mathrm{H}^{4-12 \cdot}\right.$} & 227.9846 & 227.9089 & 0.0757 \\
\hline 14 & 55 & {$\left[\mathrm{M}-1 \mathrm{H}^{\bullet}-6 \mathrm{H}_{2} \mathrm{O}-4 \mathrm{H}\right]^{4-1}$} & 253.7405 & 253.7368 & 0.0037 \\
\hline 15 & 70 & {$\left[\mathrm{M}-2 \mathrm{H}_{2} \mathrm{O}-4 \mathrm{OH}^{\bullet}+4 \mathrm{e}\right]^{4-}$} & 256.0082 & 256.0519 & -0.0437 \\
\hline 16 & 32 & {$\left[\mathrm{M}+62 \mathrm{H}_{2} \mathrm{O}-4 \mathrm{H}\right]^{4-}$} & 560.1727 & 560.1382 & 0.0345 \\
\hline 17 & 43 & {$\left[2 \mathrm{M}+26 \mathrm{H}_{2} \mathrm{O}-4 \mathrm{H}\right]^{4-}$} & 680.0935 & 680.0391 & 0.0544 \\
\hline 18 & 62 & {$\left[4 \mathrm{M}+10 \mathrm{H}_{2} \mathrm{O}-4 \mathrm{H}\right]^{4-}$} & 1172.0835 & 1172.0648 & 0.0187 \\
\hline 19 & 65 & {$\left[4 \mathrm{M}+66 \mathrm{H}_{2} \mathrm{O}-4 \mathrm{H}\right]^{4-}$} & 1424.2319 & 1424.2480 & -0.0161 \\
\hline 20 & 71 & {$\left[6 \mathrm{M}-3 \mathrm{H}^{\bullet}+16 \mathrm{H}_{2} \mathrm{O}-4 \mathrm{H}\right]^{4-3 \cdot}$} & 1762.3759 & 1762.4616 & -0.0857 \\
\hline 21 & 55 & {$\left[4 \mathrm{M}-6 \mathrm{H}_{2} \mathrm{O}-5 \mathrm{H}\right]^{5-}$} & 879.8313 & 879.8669 & -0.0356 \\
\hline 22 & 51 & {$\left[5 \mathrm{M}-2 \mathrm{H}^{\bullet}-19 \mathrm{H}_{2} \mathrm{O}-5 \mathrm{H}\right]^{5-\bullet}$} & 1058.3645 & 1058.3025 & 0.0620 \\
\hline 23 & 86 & {$\left[\mathrm{M}-9 \mathrm{H}_{2} \mathrm{O}-\mathrm{OH}^{\bullet}-6 \mathrm{H}^{6-1}\right]^{\bullet}$} & 157.1533 & 157.2115 & -0.0582 \\
\hline 24 & 84 & {$\left[\mathrm{M}-2 \mathrm{H}_{2} \mathrm{O}-3 \mathrm{OH}^{\bullet}+3 \mathrm{e}-3 \mathrm{H}\right]^{6-}$} & 173.0020 & 173.0518 & -0.0498 \\
\hline 25 & 51 & {$\left[\mathrm{M}-1 \mathrm{H}^{\bullet}-\mathrm{H}_{2} \mathrm{O}-6 \mathrm{H}\right]^{6-1 \bullet}$} & 183.8332 & 183.8562 & -0.0149 \\
\hline
\end{tabular}

aThe intensity relative to the base peak at $\mathrm{m} / \mathrm{z} 1127.0719$ in the spectrum with tallest peak set to $100 \%$.

$[\mathrm{M}-\mathrm{H}]^{-}$at $m / z 1127$ was clearly observed through the presence of singly charged ions centered at $m / z 1055\left[\mathrm{M}-4 \mathrm{H}_{2} \mathrm{O}-\right.$ $\mathrm{H}]^{-}$and $m / z 983\left[\mathrm{M}-8 \mathrm{H}_{2} \mathrm{O}-\mathrm{H}\right]^{-}$.

Along with the singly charged $\left[\mathrm{M}-n \mathrm{H}_{2} \mathrm{O}-\mathrm{H}\right]^{-}$ions, six types of singly and multiply charged simple and distonic ion clusters and solvent adducts were detected within $\mathrm{m} / \mathrm{z} 1000$ and $\mathrm{m} / \mathrm{z}$ 3000 (Figure 1 and Table 1): $\left[\mathrm{M}(\mathrm{n})-n \mathrm{H}_{2} \mathrm{O}-\mathrm{xH}\right]^{\mathrm{x}-},[\mathrm{M}(\mathrm{n})+$ $\left.\mathrm{H}_{2} \mathrm{O}(\mathrm{m})-\mathrm{xH}\right]^{\mathrm{x}-\mathrm{y} \bullet},\left[\mathrm{M}(\mathrm{n})+m \mathrm{H}_{2} \mathrm{O}(\mathrm{m})-\mathrm{yH}^{\bullet}-\mathrm{xH}\right]^{\mathrm{x}-\mathrm{y} \bullet},[\mathrm{M}(\mathrm{n})$ $\left.-m \mathrm{H}_{2} \mathrm{O}-\mathrm{yH}^{\bullet}-\mathrm{xH}\right]^{\mathrm{x}-\mathrm{y}},\left[\mathrm{M}(\mathrm{n})-m \mathrm{H}_{2} \mathrm{O}-\mathrm{yHO}^{\bullet}+\mathrm{ye}-\right.$ $\mathrm{xH}]^{(\mathrm{x}+\mathrm{y})^{-}}$and $\left[\mathrm{M}-m \mathrm{H}_{2} \mathrm{O}-\mathrm{yHO}^{\bullet}-\mathrm{zH}^{\bullet}-\mathrm{xH}\right]^{\mathrm{x}-(\mathrm{y}+\mathrm{z})}{ }^{\bullet}$.

Between $m / z 100$ and 600 (Table 1 and Scheme 3) the most intense peaks are designated to highly charged anions and distonic radical anions generated by ionization of the parent fullerenol $\mathrm{C}_{60}(\mathrm{OH})_{24}$ as in the following examples: $\left[\mathrm{M}-9 \mathrm{H}_{2} \mathrm{O}\right.$ $\left.-\mathrm{HO}^{\bullet}+5 \mathrm{H}\right]^{6-1 \bullet}$ at $m / z 157$ (Table 1, entry 23; B in Scheme 3); $\left[\mathrm{M}-2 \mathrm{H}_{2} \mathrm{O}-3 \mathrm{HO}^{\bullet}+3 \mathrm{e}-3 \mathrm{H}\right]^{6-}$ at $m / z 173$ (Table 1, entry 24;
D in Scheme 3); $\left[\mathrm{M}-1 \mathrm{H}^{\bullet}-6 \mathrm{H}_{2} \mathrm{O}-4 \mathrm{H}\right]^{4-1} \cdot$ at $\mathrm{m} / z 253$ (Table 1, entry 14; $\mathbf{E}$ in Scheme 3); and $\left[\mathrm{M}-4 \mathrm{H}^{\bullet}-4 \mathrm{H}_{2} \mathrm{O}-\right.$ $\left.8 \mathrm{HO}^{\bullet}-4 \mathrm{H}\right]^{4-4 \bullet}$ at $m / z 227$ (Table 1, entry 13; G in Scheme 3). Above $\mathrm{m} / \mathrm{z} 1500$ the most intense peaks are assigned to the highly charged protonated and distonic deprotonated molecules containing 2-6 fullerenol and up to $66 \mathrm{H}_{2} \mathrm{O}$ clusters.

Formation of these ions can be rationalized by the mechanisms shown in Scheme 1 and graphically depicted in Scheme 3. One can suppose that, in the electrospray source, M1-fullerenyl and M2-fullerenoxyl radicals are formed by neutral cleavage of $\mathrm{C}-\mathrm{OH}$ and $\mathrm{O}-\mathrm{H}$ bonds, respectively. As soon as fullerenyl radicals M1 containing a total of less than eight odd electrons with random distribution are generated, they readily capture free electrons present in the gas (due to cosmic rays or background radiation) to form fullerenide carbanion M3, while the fullerenoxyl radicals M2 do not capture free electrons, thus 
(a) $\mathrm{C}_{60}(\mathrm{OH})_{24}$ in water

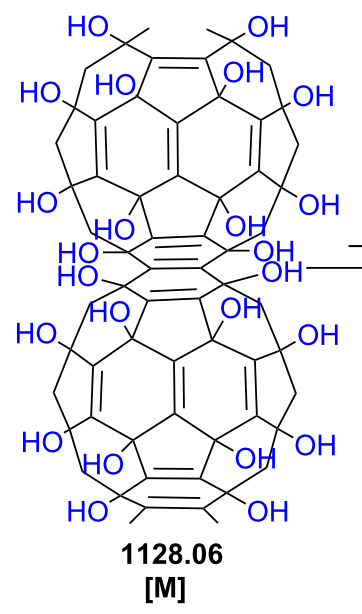

[M]

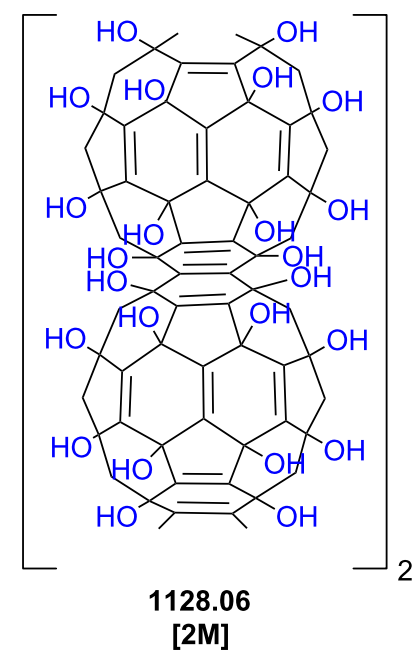

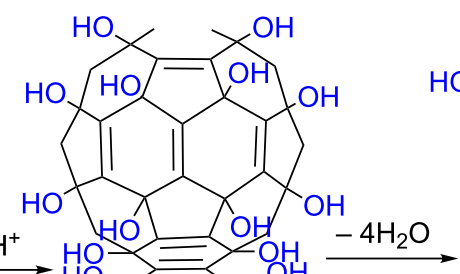

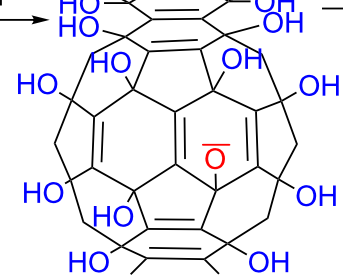

1127.07

$[\mathrm{M}-\mathrm{H}]^{-}$

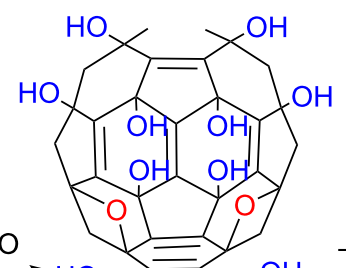

$\mathrm{HO}$

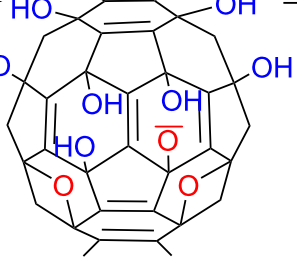

1055.02

$\left[\mathrm{M}-4 \mathrm{H}_{2} \mathrm{O}-\mathrm{H}^{-}\right.$
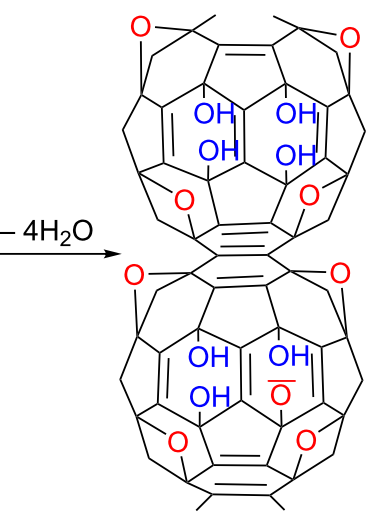

983.95

$\left[\mathrm{M}-8 \mathrm{H}_{2} \mathrm{O}-\mathrm{H}^{-}\right.$

(b) $\mathrm{C}_{60}(\mathrm{OH})_{24}$ in ammonia solution
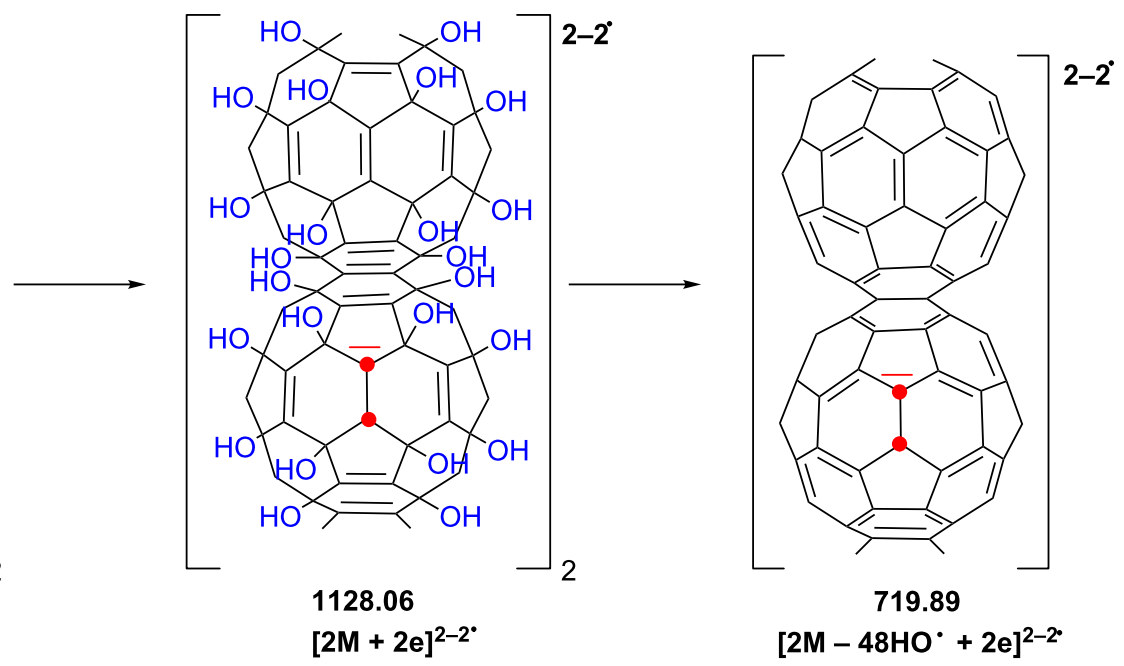

$=$ fullerenide anion

$=$ fullerenyl radical

Scheme 2: Examples of proposed structures for the main deprotonated molecules and final distonic molecular ion observed by (-)ESI-MS of $\mathrm{C}_{60}(\mathrm{OH})_{24}$ in pure water (a) and aqueous ammonia solution (b).

generating fullerenate anions M4. While only a few M1-fullerenyl radicals were detected as distonic anions [M(m) - $\left.n \mathrm{H}_{2} \mathrm{O}-\mathrm{yHO}^{\bullet}-3 \mathrm{H}\right]^{3-\mathrm{y} \bullet}$ at $m / z \quad 309,335$ and 781, fullerenoxyl radicals are much more resistant against free electrons and can be identified as abundant singly and multiply charged molecular anions containing up to 12 fullerenoxyl odd electrons.

A particular case is the abundant distonic anion $\left[\mathrm{M}-4 \mathrm{H}_{2} \mathrm{O}-\right.$ $\left.8 \mathrm{HO}^{\bullet}-4 \mathrm{H}^{\bullet}-4 \mathrm{H}\right]^{4-12 \cdot}$ at $\mathrm{m} / \mathrm{z} 227$ (entry 13 in Table 1, and $\mathbf{C}$ in Scheme 3), which appears to contain four fullerenoxyl radicals and eight fullerenyl radicals. In fact, the partial $\pi$-bond reconstruction by rehybridization and redistribution of odd fullerenyl electrons of intermediate $\mathbf{C}$ should account for the distonic anion $\mathbf{G}$. The structure of the species $\left[\mathrm{M}-\mathrm{xH}_{2} \mathrm{O}-\mathrm{yHO}^{\bullet}+\mathrm{ye}-\right.$ $\mathrm{zH}]^{(\mathrm{z}+\mathrm{y})^{-}}$depicted as a high-range of relative abundance in the mass spectra, due to a loss of protons from fullerenylcarbanion-containing species $\mathbf{M 3}$, could be assigned to fullerenide-fullerenate carbanion species M6 (B and D in Scheme 3).

\section{Fullerenol in ammonia aqueous solution}

In order to enhance the ionization process of the fullerenol, small amounts of aqueous ammonia were used. Very abundant doubly charged ions with good intensity corresponding to dimeric species were observed for fullerenol $\mathrm{C}_{60}(\mathrm{OH})_{24}$ in aqueous ammonia solution recorded at $4.5 \mathrm{kV}$ capillary voltage and $400 \mathrm{~V}$ fragmentor voltage (Figure 2). 


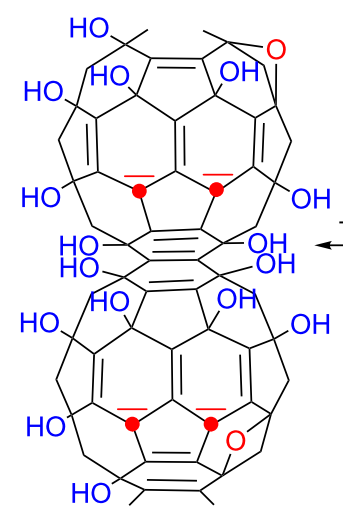

A

$256.05(70)$

$\left[\mathrm{M}-2 \mathrm{H}_{2} \mathrm{O}-4 \mathrm{OH}+4 \mathrm{e}\right]^{4-}$

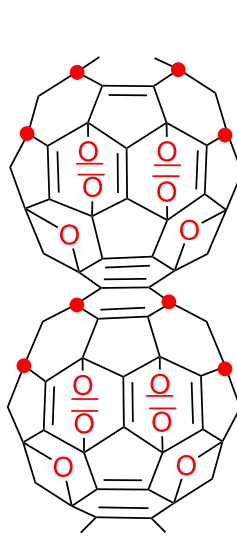

C

227.91 (71)

$\left[\mathrm{M}-4 \mathrm{H}_{2} \mathrm{O}-8 \mathrm{HO}^{\circ}-4 \mathrm{H}^{\circ}-4 \mathrm{H}^{4-12}\right.$
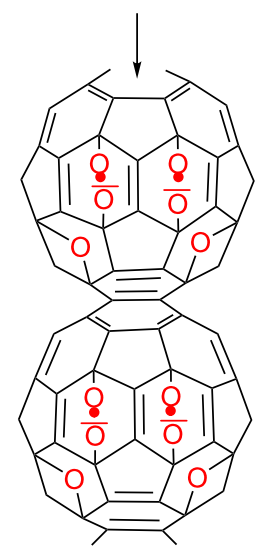

G

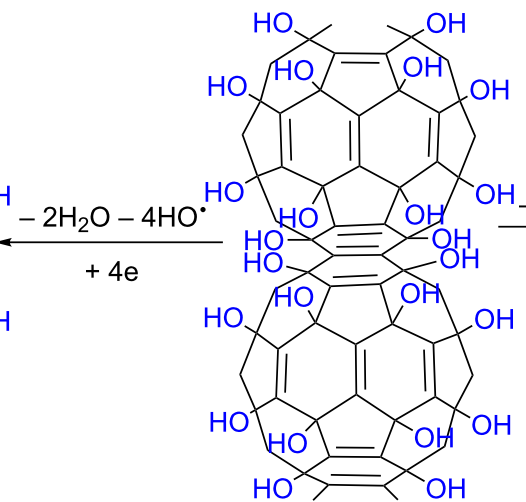

1128.06

[M]
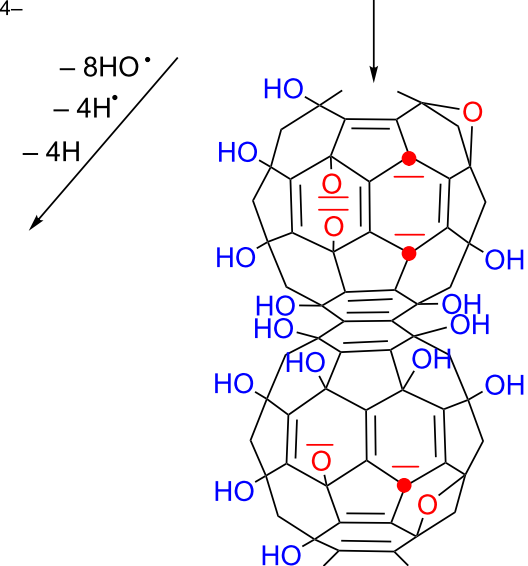

D

173.05 (84)

$\left[\mathrm{M}-2 \mathrm{H}_{2} \mathrm{O}-3 \mathrm{HO}^{\circ}+3 \mathrm{e}-3 \mathrm{H}^{6-}\right.$

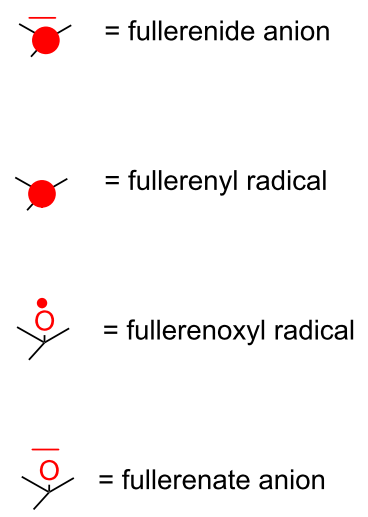

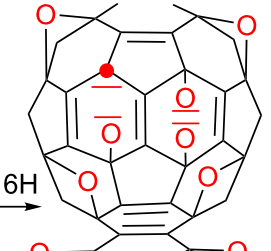

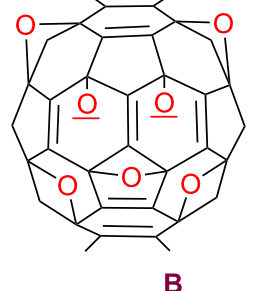

157.21 (86)

$\left[\mathrm{M}-9 \mathrm{H}_{2} \mathrm{O}-1 \mathrm{OH}-6 \mathrm{H}\right]^{6-}$
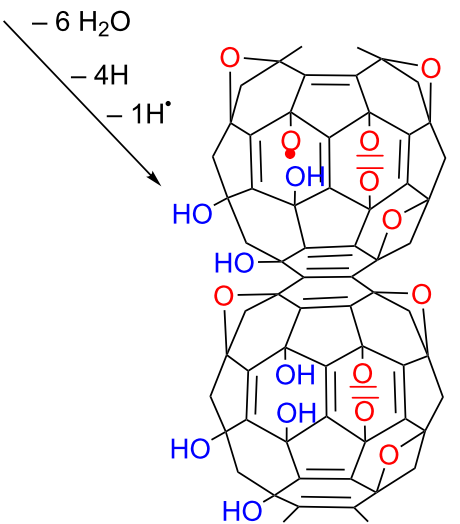

253.74 (55)

$\left[\mathrm{M}-6 \mathrm{H}_{2} \mathrm{O}-1 \mathrm{H}^{\circ}-4 \mathrm{H}\right]^{4-}$

227.91 (71)

$\left[\mathrm{M}-4 \mathrm{H}_{2} \mathrm{O}-8 \mathrm{HO}^{\circ}-4 \mathrm{H}^{\circ}-4 \mathrm{H}^{4-4 \cdot}\right.$ 


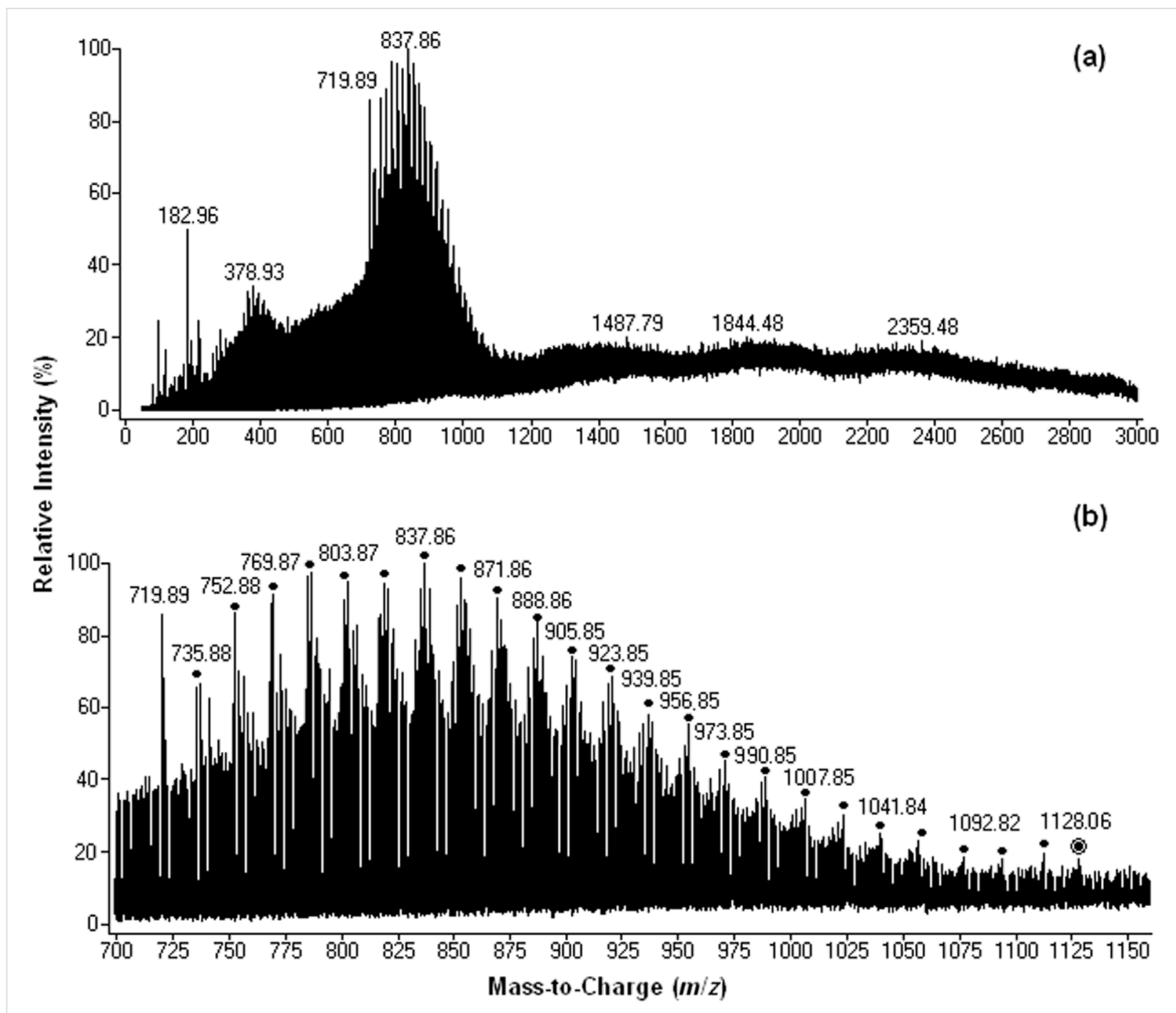

Figure 2: Negative-ion mass spectra of a $0.5 \times 10^{-5} \mathrm{M}$ aqueous solution of $\mathrm{C}_{60}(\mathrm{OH})_{24}$ in ammonia solution: (a) full scan spectrum; (b) $\mathrm{m} / \mathrm{z}$ ranges of $700-1200$.

Consecutive losses of $\mathrm{m} / \mathrm{z} 17$ units are attributed to the neutral loss of $n \mathrm{OH}$ radicals $(n=2-48)$, followed by the rehybridization and redistribution of odd electrons of fullerenyl radical anion, accounting for the formation of a final molecular anion $[2 \mathrm{M}-48 \mathrm{OH}+2 \mathrm{e}]^{2-}$ as observed at $m / z 720$ and depicted in Scheme 2. Taking into account the moderate electron affinity of fullerenols $[32,33]$ and the fact that earlier extensive studies focused on pristine fullerene anion radicals [34-37] unquestionably confirmed their generation by electron transfer from various electron donors (aliphatic and aromatic amines especially) [38,39], one can postulate that, under ESI conditions, a distonic radical carbanion $\left[\left(\mathrm{C}_{60}(\mathrm{OH})_{24}{ }^{-\bullet}\right)_{2}\right]^{2-\bullet}$ is first generated by electron transfer from $\mathrm{H}_{2} \mathrm{~N}^{-}$produced by ammonia ionization and then undergoes consecutive $\mathrm{OH}$ radical losses and electron redistribution until the entire reconstruction of the electronic structure of pristine fullerene is achieved.

\section{Positive-ionization-mode mass spectra}

In Figure 3 are shown positive-ion-mode ESI mass spectra of $\mathrm{C}_{60}(\mathrm{OH})_{24}$ with the addition of (a) $10 \mu \mathrm{L} 3 \times 10^{-1} \mathrm{M}$ and (b) $10 \mu \mathrm{L} 2 \times 10^{-2} \mathrm{M}$ aqueous ammonia solution. All of the observed ion species were obtained under $4.5 \mathrm{kV}$ capillary voltage and $400 \mathrm{~V}$ fragmentor voltage.

With regard to molecular species and their stability, the positive-ion spectra of fullerenol in the presence of aqueous ammonia were significantly different from the negative-ion spectra. While the relative intensities of 2- to 6-protonated fullerenol with dilute $2 \times 10^{-2} \mathrm{M}$ ammonia aqueous solution were about threefold smaller than those observed under negative ionization conditions, the relative intensities recorded in the presence of $10 \mu \mathrm{L} 3 \times 10^{-1} \mathrm{M}$ ammonia solution were about tenfold smaller than in the negative mode. 


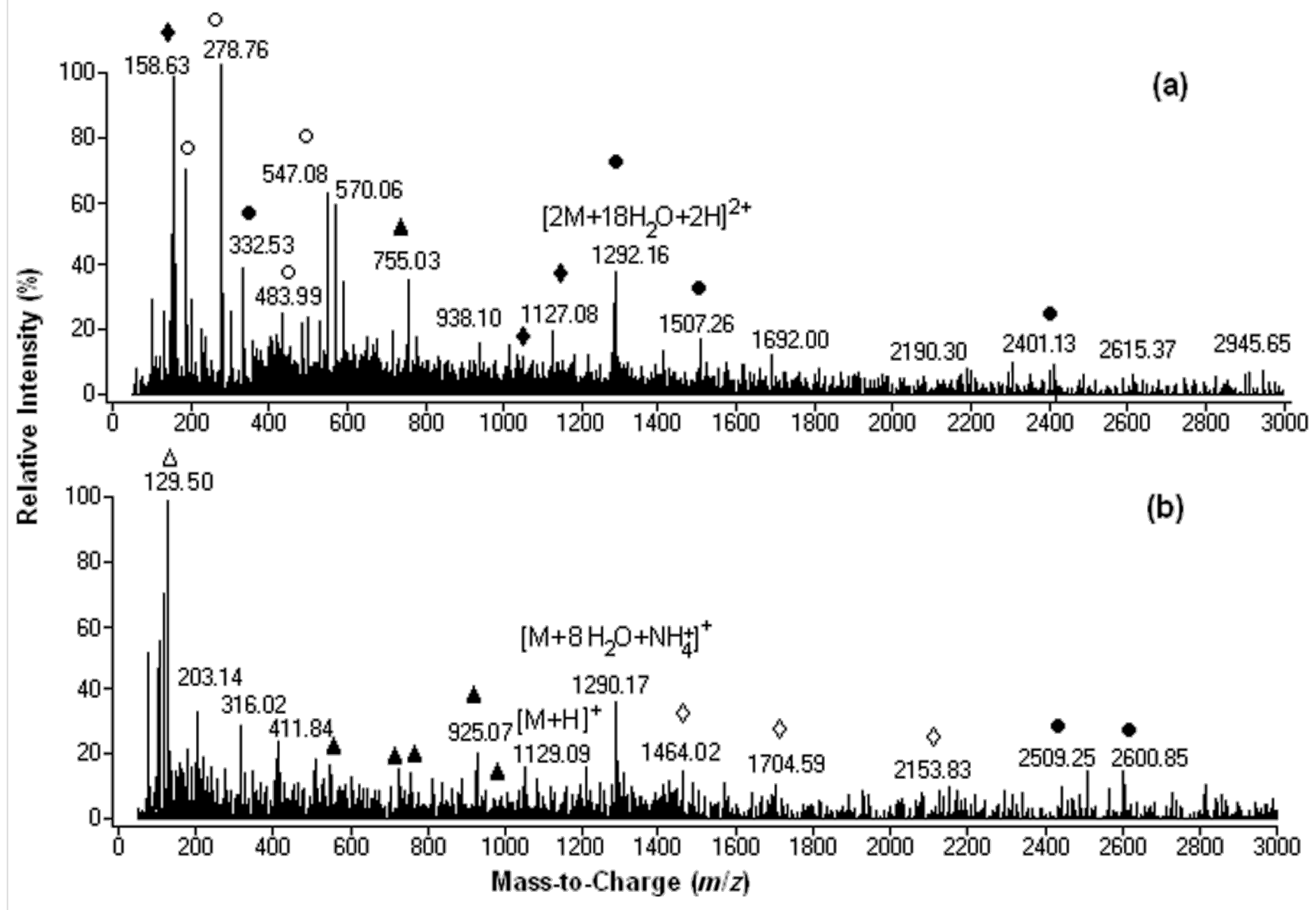

Figure 3: Positive ionization ESI mass spectrum of $\mathrm{C}_{60}(\mathrm{OH})_{24}$ in $(\mathrm{a}) 3 \times 10^{-1} \mathrm{M}(\mathrm{b}) 2 \times 10^{-2} \mathrm{M}$ aqueous ammonia solution. $\left(\bullet\left[\mathrm{M}(\mathrm{n})+\mathrm{H} \mathrm{H}_{2} \mathrm{O}(\mathrm{m})+\mathrm{xH}\right]^{\mathrm{x}+}\right.$ $\Delta[\mathrm{M}(\mathrm{n})-\mathrm{OH}(\mathrm{m})+\mathrm{xH}]^{\mathrm{x}+}, \bullet\left[\mathrm{M}(\mathrm{n})-\mathrm{H}_{2} \mathrm{O}(\mathrm{m})+n \mathrm{NH}_{3}+\mathrm{xH}\right]^{\mathrm{x}+}, \circ\left[\mathrm{M}(\mathrm{n})-\mathrm{H}_{2} \mathrm{O}(\mathrm{m})+\mathrm{xH}\right]^{\mathrm{x}}, \Delta\left[\mathrm{M}(\mathrm{n})-\mathrm{OH}(\mathrm{m})+\mathrm{yNH}{ }_{4}^{+}+\mathrm{xH}\right]^{(\mathrm{x}+\mathrm{y})+}, \diamond\left[\mathrm{M}(\mathrm{n})+\mathrm{H}_{2} \mathrm{O}(\mathrm{m})+n N H_{3}\right.$ $+\mathrm{xH}]^{\mathrm{x}+}$ ).

While the predominant base peak observed for $\mathrm{C}_{60}(\mathrm{OH})_{24}$ in the negative mode was $[\mathrm{M}-\mathrm{H}]^{-}$those observed in the positive mode were $\left[\mathrm{M}-12 \mathrm{H}_{2} \mathrm{O}+2 \mathrm{NH}_{3}+6 \mathrm{H}\right]^{6+}(96 \%)$ and $\left[\mathrm{M}-\mathrm{H}_{2} \mathrm{O}\right.$ $+4 \mathrm{H}]^{4+}(100 \%)$ (see Supporting Information File 1, Table S1, entries 9 and 7; $\mathbf{D}$ and $\mathbf{E}$ in Scheme 4) with $10 \mu \mathrm{L} 2 \times 10^{-2} \mathrm{M}$ aqueous ammonia solution and $\left[\mathrm{M}-24 \mathrm{HO}+3 \mathrm{NH}_{4}{ }^{+}+3 \mathrm{H}\right]^{6+}$ (100\%) (see Supporting Information File 1, Table S1, entry 9; F in Scheme 4) with $10 \mu \mathrm{L} 3 \times 10^{-1} \mathrm{M}$ aqueous ammonia solution.

The relative intensity of singly protonated fullerenol $[\mathrm{M}+\mathrm{H}]^{+}$ (9\%) at $m / z 1129$ was very low (Supporting Information File 1, entry 5 in Table S1 and $\mathbf{C}$ in Scheme 4). On the other hand, while under negative-ionization-mode conditions abundant $\left[\mathrm{M}(\mathrm{n})+\mathrm{H}_{2} \mathrm{O}(\mathrm{m})-\mathrm{xH}\right]^{\mathrm{x}^{-}}$clustered ions with medium and high intensity are formed up to $n=6$ and $m=66$, only very few dimers, one tetramer and one pentamer with very low intensity were observed under positive-mode conditions.

\section{Conclusion}

It is demonstrated here that electrospray mass spectrometry is a perfectly suitable method to study fullerenol $\mathrm{C}_{60}(\mathrm{OH})_{24}$ in pure water and in the presence of aqueous ammonia solution in the negative and positive ionization modes, under the optimal capillary and fragmentor voltage. While the predominant base peak observed for $\mathrm{C}_{60}(\mathrm{OH})_{24}$ in the negative-ionization mode was $[\mathrm{M}-\mathrm{H}]^{-}$at $m / z 1127$, those observed in the positive mode were multiply charged $\left[\mathrm{M}-\mathrm{H}_{2} \mathrm{O}+4 \mathrm{H}\right]^{4-}$ at $m / z 279(100 \%)$ and $[\mathrm{M}$ $\left.-12 \mathrm{H}_{2} \mathrm{O}+2 \mathrm{NH}_{3}+6 \mathrm{H}\right]^{6+}$ at $m / z 158(96 \%)$.

We show that in the negative ionization mode, fullerenol $\mathrm{C}_{60}(\mathrm{OH})_{24}$ readily lose not only $\mathrm{H}_{2} \mathrm{O}$ but also lose $\mathrm{OH}^{\bullet}$ and $\mathrm{H}^{\bullet}$ radicals giving rise to ion species that contain long-living fullerenoxyl radicals and/or short-living fullerenyl radicals, respectively. Affinity of short-lived fullerenyl radicals for free electrons to form carbanion-like fullerenyde charges on the C60 cage revealed an atypical pattern, characterized by neutral 


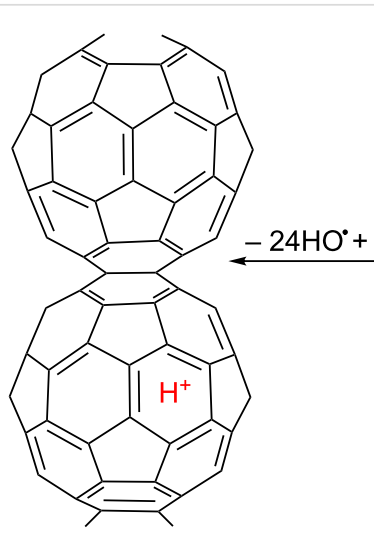

A 721.02 (12)

$\left[\mathrm{M}-24 \mathrm{HO}^{\circ}+\mathrm{H}\right]^{+}$

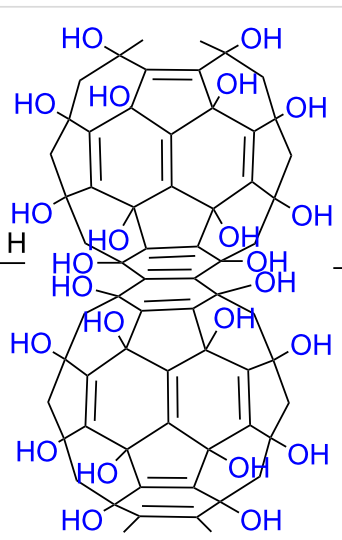

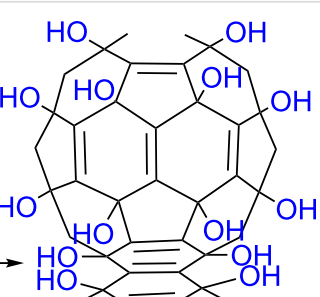

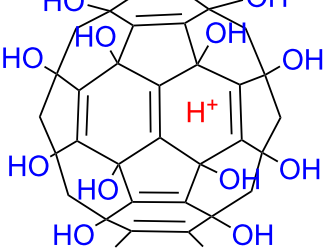

B 1128.06

[M]

C 1129.09 (9)

$[\mathrm{M}+\mathrm{H}]^{+}$

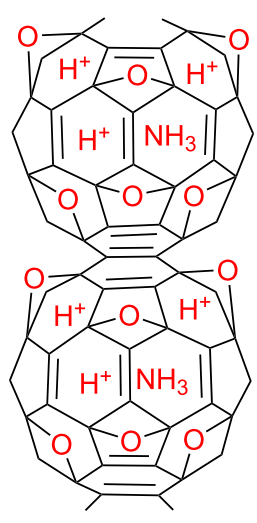

D $158.63(96)$

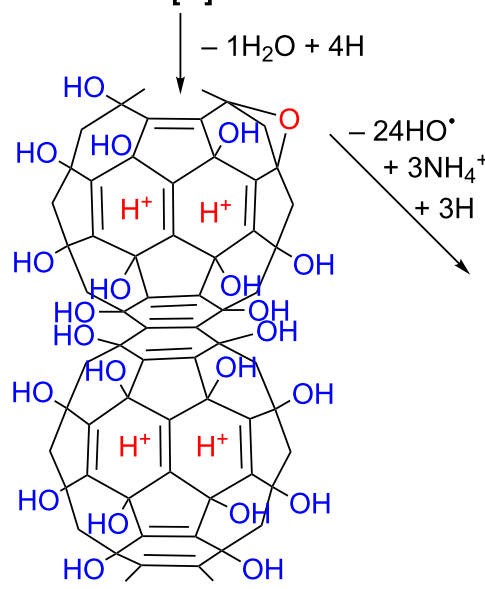

E 278.76 (100)

$\left[\mathrm{M}-1 \mathrm{H}_{2} \mathrm{O}+4 \mathrm{H}\right]^{4+}$

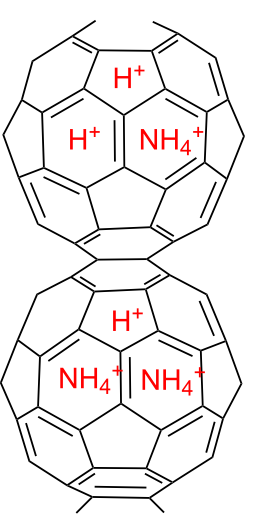

F 129.50 (100)

$\left[\mathrm{M}-24 \mathrm{HO}^{\circ}+3 \mathrm{NH}_{4}^{+}+3 \mathrm{H}\right]^{6+}$

Scheme 4: Proposed (+)ESI-MS ionization mechanisms for fullerenol $\mathrm{C}_{60}(\mathrm{OH})_{24}$ in ammonia solution.

cleavage of $\mathrm{C}-\mathrm{OH}$ bonds to form fullerenyl radicals, which can capture free electrons to generate negative charges, while fullerenoxyl radicals produced by $\mathrm{O}-\mathrm{H}$ bond cleavage are much more stable against the free radicals.

In addition to simple bond cleavages, fullerenol ions containing at least eight fullerenyl radicals undergo an unanticipated gasphase rearrangement that involves the partial (in the negative mode from pure aqueous media) or total (in the positive mode and negative mode from ammonia aqueous solutions) $\pi$-bond reconstruction of the $\mathrm{C} 60$ cage by rehybridization and redistribution of odd electrons of fullerenyl radicals to form $\mathrm{C}_{60}$ anions or cations, respectively.

\section{Experimental Materials}

All chemicals and reagents used for fullerenol preparation and HPLC/ESI-MS analyses were commercially available (SigmaAldrich, St. Louis, MO, USA). The high purity $\mathrm{C}_{60}(\mathrm{OH})_{24}$ sample was prepared as previously described [14,15] (see Supporting Information File 1). Freshly produced ultrapure water (TKA Lab TowerEDI $0.067-0.080 \mu \mathrm{S} / \mathrm{cm}$ ) was used for sample preparation and as the mobile phase. The Tuning Mix solution for Q-TOF parameter optimization was purchased from Agilent Technologies.

\section{Sample preparation}

A stock solution containing $0.5 \times 10^{-5} \mathrm{M}$ fullerenol $\mathrm{C}_{60}(\mathrm{OH})_{24}$ was prepared by dissolution of dry fullerenol in ultrapure water, filtered and injected directly into the HPLC system. In order to prepare the samples with the ammonia medium, to each $1 \mathrm{~mL}$ of the $0.5 \times 10^{-5} \mathrm{M}$ fullerenol stock solution, $10 \mu \mathrm{L}$ of $2 \times 10^{-2} \mathrm{M}$ or $3 \times 10^{-1} \mathrm{M}$ aqueous ammonia was added for two series of assays.

\section{HPLC separation conditions}

HPLC separation was performed on a chromatographic system Agilent 1200 series separation module equipped with a binary 
pump, heated column compartment, autosampler and diode array detector. Separations were achieved using a new Agilent Zorbax SB-C18 reverse phase column $(4.6 \mathrm{~mm} \times 150 \mathrm{~mm}$, $5 \mu \mathrm{m}$ particle size) with a column temperature kept at $35^{\circ} \mathrm{C}$. Using a $20 \mu \mathrm{L}$ injection volume, the fullerenol $\mathrm{C}_{60}(\mathrm{OH})_{24}$ was monitored through UV detection at $280 \mathrm{~nm}$ for a total runtime of 30 minutes at a flow rate of $1 \mathrm{~mL} / \mathrm{min}$. Because the fullerenol $\mathrm{C}_{60}(\mathrm{OH})_{24}$ is sparingly soluble in alcohols and acetonitrile, ultrapure water was used as the mobile phase for the HPLC separation and ESI-MS measurements, in negative- and positive-ionization mode. The mobile phase was filtered through a $0.45 \mu \mathrm{m}$ filter and degassed for 30 minutes by sonication.

A typical chromatogram of the aqueous solution of $\mathrm{C}_{60}(\mathrm{OH})_{24}$ (see Supporting Information File 1, Figure S1a) indicates a very small peak at approximately $1.5 \mathrm{~min}$ retention time, corresponding to contaminants from the sample, and a major peak at $2.6 \mathrm{~min}$, corresponding to the analyte. The blank chromatogram (see Supporting Information File 1, Figure S1b) showed no peaks in the HPLC beside the solvent front. Hence, it is a clear evidence that the used column allows separation of $\mathrm{C}_{60}(\mathrm{OH})_{24}$, and it is clear that fullerenol is essentially an individual pure compound.

\section{ESI-MS analysis}

Mass spectrometry results were obtained using an Agilent 6520 Series Accurate-Mass Quadrupole Time-of-Flight (Q-TOF) LC/ MS. The solutions were introduced into the electrospray ion source (ESI) after HPLC separation via a 4:1 splitter at a flowrate of $0.2 \mathrm{~mL} / \mathrm{min}$. During the experiments, the following Q/ TOF MS parameters were optimized: electrospray ionization (positive- and negative-ion mode), drying gas $\left(\mathrm{N}_{2}\right)$ flow rate, drying-gas temperature, nebulizer pressure, capillary voltage, and fragmentor voltage. The mass scale was calibrated by the standard calibration procedure with compounds provided by the manufacturer. Data were collected and processed by using MassHunter workstation data acquisition software for the 6200/ 6500 series, version B.01.03. The calculated $\mathrm{m} / \mathrm{z}$ values are based on the weight of the most abundant isotopes (monoisotopic mass).

\section{The key experimental observations}

The first experiments studied the effect of ESI source parameters and mobile phase composition on the formation of fullerenol $\mathrm{C}_{60}(\mathrm{OH})_{24}$ ions under negative and positive ionization mode. The fragmentor voltage and capillary voltage were the first parameters to be optimized because they have the greatest impact on the sensitivity and fragmentation. Consequently, the first objective was to find the optimum values for the fragmentor and capillary voltage that provides a strong molecular ion and a good relative abundance. The use of high voltages generates a greater signal, but this needs to be balanced with an increased background-to-noise ratio at the higher corona-current settings.

To optimize the conditions for obtaining maximum intensity, the capillary voltage was varied between 2.0 and $4.5 \mathrm{kV}$ and the fragmentor voltage was varied between 100 and $400 \mathrm{~V}$. Typical values for the other source parameters were: drying gas $\left(\mathrm{N}_{2}\right)$ flow rate $8.0 \mathrm{~L} / \mathrm{min}$; drying-gas temperature $325^{\circ} \mathrm{C}$; nebulizer pressure 35 psig, skimmer $58 \mathrm{~V}$ and the octopol RF $750 \mathrm{~V}$. The full-scan mass spectra of the investigated compounds were acquired in the range $m / z 100-3000$. The results are summarized in Figure S2 in Supporting Information File 1 showing the ESI-MS reference grid for $\mathrm{C}_{60}(\mathrm{OH})_{24}$ as a function of fragmentor and capillary voltage in negative- and positive-ionization modes.

The experiments that were carried out at capillary voltage values of $2.0-4.0 \mathrm{kV}$ and fragmentor voltage of 100-300 V (Supporting Information File 1, Figure S3a-c) did not affect any ionization and only peaks associated with unknown contaminants were observed at $\mathrm{m} / \mathrm{z}$ 113, 294 and 420, detected in ultrapure water (Supporting Information File 1, Figure S1c) under negative-ionization-mode conditions. However, the fullerenol ionization takes place with good peak intensity distribution in the electrospray source at $4.5 \mathrm{kV}$ capillary voltage and $400 \mathrm{~V}$ fragmentor voltage in negative-ionization mode (Figure 1 and Supporting Information File 1, Figure S3d) and at capillary voltage range of $3.0-4.5 \mathrm{eV}$ in positive-ionization mode. Although a capillary voltage of $4.5 \mathrm{kV}$ was recently reported to effect positive ionization of the MER commercial fullerenol $\mathrm{C}_{60}(\mathrm{OH})_{16}(\mathrm{ONa})_{8}[23]$ the reported results based only on a full scan spectrum of MER fullerenol sample were completely different from the current reported results.

\section{Supporting Information}

\section{Supporting Information File 1}

Additional material.

[http://www.beilstein-journals.org/bjoc/content/ supplementary/1860-5397-9-145-S1.pdf]

\section{Acknowledgements}

This work was supported by a grant of the Romanian National Authority for Scientific Research, CNCS - UEFISCDI, project number PN-II-ID-PCCE-2011-2-0028 and the European Social Fund "Cristofor I. Simionescu" Postdoctoral Fellowship Program (ID POSDRU/89/1.5/S/55216), Sectoral Operational Program Human Resources Development 2007-2013. 


\section{References}

1. Jin, H.; Chen, W. Q.; Tang, X. W.; Chiang, L. Y.; Yang, C. Y.; Schloss, J. V.; Wu, J. Y. Neurosci. Res. 2000, 62, 600-607. doi:10.1002/1097-4547(20001115)62:4<600::AID-JNR15>3.0.CO;2-F

2. Gelderman, M. P.; Simakova, O.; Clogston, J. D.; Patri, A. K.; Siddiqui, S. F.; Vostal, A. C.; Simak, J. Int. J. Nanomed. 2008, 3, 59-68. doi:10.2147/IJN.S1680

3. Lu, L.-H.; Lee, Y.-T.; Chen, H.-W.; Chiang, L. Y.; Huang, H.-C. Br. J. Pharmacol. 1998, 123, 1097-1102. doi:10.1038/sj.bjp.0701722

4. Silva, G. A. Nat. Rev. Neurosci. 2006, 65-74. doi:10.1038/nrn1827

5. Silva, G. A. Surg. Neurol. 2005, 63, 301-306. doi:10.1016/j.surneu.2004.06.008

6. Dugan, L. L.; Lovett, E. G.; Quick, K. L.; Lotharius, J.; Lin, T. T.; O'Malley, K. L. Parkinsonism Rel. Disord. 2001, 7, 243-246. doi:10.1016/S1353-8020(00)00064-X

7. Dugan, L. L.; Gabrielsen, J. K.; Yu, S. P.; Lin, T.-S.; Choi, D. W. Neurobiology of Diseases. 1996, 3, 129-135. doi:10.1006/nbdi.1996.0013

8. Injac, R.; Radic, N.; Govedarica, B.; Perse, M.; Cerar, A.; Djordjevic, A.; Strukelj, B. Pharmacol. Rep. 2009, 61, 335-342.

9. Injac, R.; Perse, M.; Cerne, M.; Potocnik, N.; Radic, N.; Govedarica, B.; Djordjevic, A.; Cerar, A.; Strukelj, B. Biomaterials 2009, 30, 1184-1196. doi:10.1016/j.biomaterials.2008.10.060

10. Injac, R.; Boskovic, M.; Perse, M.; Koprivec-Furlan, E.; Cerar, A.; Djordjevic, A.; Strukelj, B. Pharmacol. Rep. 2008, 60, 742-749.

11. Chaudhuri, P.; Paraskar, A.; Sonii, S.; Mashelkar, R. A.; Sengupta, S. ACS Nano 2009, 3, 2505-2514. doi:10.1021/nn900318y

12. Yin, J.-J.; Lao, F.; Meng, J.; Fu, P. P.; Zhao, Y.; Xing, G.; Gao, X.; Sun, B.; Wang, P. C.; Chen, C.; Liang, X.-J. Mol. Pharmacol. 2008, 74, 1132-1140. doi:10.1124/mol.108.048348

13. Zhu, J.; Ji, Z.; Wang, J.; Sun, R.; Zhang, X.; Gao, Y.; Sun, H.; Liu, Y.; Wang, Z.; Li, A. Q.; Ma, J.; Wang, T.; Jia, G.; Gu, Y. Small 2008, 4, 1168-1175. doi:10.1002/smll.200701219

14. Pinteala, M.; Dascalu, A.; Ungurenasu, C. Int. J. Nanomed. 2009, 4, 193-199. doi:10.2147/IJN.S6630

15. Mrdanovic, J. Z.; Solajic, S. V.; Bogdanovic, V. V.; Djordjevic, A. N.; Bogdanovic, G. M.; ljac, R. D.; Rakocevic, Z. L. J. Dig. J. Nanomater. Biostruct. 2012, 7, 673-686.

16. Bogdanović, G.; Kojić, V.; Đordević, A.; Canadanović-Brunet, J.; Vojinović-Miloradov, M.; Baltić, V. V. Toxicol. in Vitro 2004, 18, 629-637. doi:10.1016/j.tiv.2004.02.010

17. Chiang, L. Y.; Upasani, R. B.; Swirczewski, J. W.; Soled, S. J. Am. Chem. Soc. 1993, 115, 5453-5457. doi:10.1021/ja00066a014

18. Schneider, N. S.; Darwish, A. D.; Kroto, H. W.; Taylor, R.; Walton, D. R. M. J. Chem. Soc., Chem. Commun. 1994, 463-464. doi:10.1039/C39940000463

19. Chiang, L. Y.; Upasani, R. B.; Swirczewski, J. W. J. Am. Chem. Soc. 1992, 114, 10154-10157. doi:10.1021/ja00052a010

20. Husebo, L. O.; Sitharaman, B.; Furukawa, K.; Kato, T.; Wilson, L. J. J. Am. Chem. Soc. 2004, 126, 12055-12064. doi:10.1021/ja047593o

21. Singh, R.; Goswami, T. J. Phys. Org. Chem. 2008, 21, 225-236. doi:10.1002/poc.1304

22. Isaacson, C. W.; Kleber, M.; Field, J. A. Environ. Sci. Technol. 2009, 43, 6463-6474. doi:10.1021/es900692e

23. Chao, T.-C.; Guixue, S.; Hansmeier, N.; Westerhoff, P.; Herckes, P.; Halden, R. U. Anal. Chem. 2011, 83, 1777-1783. doi:10.1021/ac1031379

24. Singh, R.; Goswami, T. Thermochim. Acta 2011, 513, 60-67. doi:10.1016/j.tca.2010.11.012
25. Bobylev, A. G.; Kornev, A. B.; Bobyleva, L. G.; Shpagina, M. D.; Fadeeva, I. S.; Fadeev, R. S.; Deryabin, D. G.; Balzarini, J.; Troshin, P. A.; Podlubnay, Z. A. Org. Biomol. Chem. 2011, 9 , 5714-5719. doi:10.1039/c1ob05067b

26. Kokubo, K.; Matsubayashi, K.; Tategaki, H.; Takada, H.; Oshima, T. ACS Nano 2008, 2, 327-333. doi:10.1021/nn700151z

27. Kokubo, K.; Shirakawa, S.; Kobayashi, N.; Aoshima, H.; Oshima, T. Nano Res. 2011, 4, 204-215. doi:10.1007/s12274-010-0071-z

28. Semenov, K. N.; Letenko, D. G.; Charykov, N. A.; Nikitin, V. A.; Matuzenko, M. Y.; Keskinov, V. A.; Postnov, V. N.; Kopyrin, A. A. Russ. J. Appl. Chem. 2010, 83, 2076-2080. doi:10.1134/S1070427210120025

29. Powell, W. H.; Cozzi, F.; Moss, G. P.; Thilgen, C.; Hwu, R. J.-R.; Yeryn, A. Pure Appl. Chem. 2002, 74, 629-695. doi:10.1351/pac200274040629

30. Reeks, L. P.; Eichinger, P. C. H.; Bowie, J. H. Rapid Commun. Mass Spectrom. 1993, 7, 286-287. doi:10.1002/rcm.1290070405

31. Morishetti, K. M.; Sripadi, P.; Mariappandar, V.; Ren, J. Int. J. Mass Spectrom. 2011, 299, 169-177. doi:10.1016/j.jms.2010.10.025

32. Mohan, H.; Palit, D. K.; Mittal, J. P.; Chiang, L. Y.; Asmus, K.-D.; Guldi, D. M. J. Chem. Soc., Faraday Trans. 1998, 94, 359-363. doi:10.1039/a705293f

33. Mohan, H.; Chiang, L. Y.; Mittal, J. P. Res. Chem. Intermed. 1997, 23, 403-414. doi:10.1163/156856797X00150

34. Arbogast, J. W.; Foote, C. S.; Kao, M. J. Am. Chem. Soc. 1992, 114, 2277-2279. doi:10.1021/ja00032a063

35. Biczok, L.; Linschitz, H.; Walter, R. I. Chem. Phys. Lett. 1992, 195, 339-346. doi:10.1016/0009-2614(92)85613-F

36. Stasko, A.; Brezova, V.; Biskupic, S.; Dinse, K.-P.; Schweitzer, P; Baumgarten, M. J. Phys. Chem. 1995, 99, 8782-8789. doi:10.1021/j100021a052

37. Dimitrijevic, N. M.; Kamat, P. V. J. Phys. Chem. 1993, 97, 7623-7626. doi:10.1021/j100131a035

38. Brezova, V.; Stasko, A.; Rapta, P.; Domschke, G.; Bartl, A.; Dunsch, L. J. Phys. Chem. 1995, 99, 16234-16241. doi:10.1021/j100044a006

39. Janaki, J.; Premila, M.; Goplan, P.; Sastry, V. S.; Sundar, C. S. Thermochim. Acta 2000, 356, 109-116. doi:10.1016/S0040-6031(00)00477-9

\section{License and Terms}

This is an Open Access article under the terms of the Creative Commons Attribution License (http://creativecommons.org/licenses/by/2.0), which permits unrestricted use, distribution, and reproduction in any medium, provided the original work is properly cited.

The license is subject to the Beilstein Journal of Organic Chemistry terms and conditions: (http://www.beilstein-journals.org/bjoc)

The definitive version of this article is the electronic one which can be found at: doi:10.3762/bjoc. 9.145 